\title{
MANAJEMEN PARTISIPASI MASYARAKAT DALAM PENDIDIKAN PADA MTS MUHAMMADIYAH 3 AL-FURQON BANJARMASIN
}

\author{
Abdul Khaliqa \\ Dosen Fakultas Tarbiyah IAIN Antasari Banjarmasin \\ Jalan A. Yani Km 4,5 Banjarmasin
}

\begin{abstract}
Schools as formal educational institutions that have separate management in the management of education, have thus become increasingly necessary. Therefore collaboration between public agencies should be developed in synergy, given the interests and ideals alike that saves and brighten the future of our nation. Forms of community participation in education in MTs Muhammadiyah $3 \mathrm{Al}$ Furqan Banjarmasin quite diverse, namely 1) participation as a board member school committee, 2) participation in various activities at the school, and 3) community participation in maintaining security madrasah. Strategies and approaches that have been done in order to foster and develop community participation in education in MTs Muhammadiyah 3 Al Furqan Banjarmasin covers three areas: 1) Identify the Problem; 2) The treatment and approach; and 3) Guidance.
\end{abstract}

Keywords: Management, and Public Participation.

\section{PENDAHULUAN}

Peningkatan kualitas sumber daya manusia merupakan kebutuhan mutlak, terutama dalam menghadapi perubahan dan perkembangan yang pesat dalam bidang ilmu pengetahuan dan teknologi. Kebutuhan tersebut akan lebih terasa lagi dalam memasuki era pasar bebas ASEAN dan Asia-Pasifik 2020, yang mana pada semua aspek kehidupan mempersyaratkan pengetahuan dan keterampilan yang memadai. Menurut survey Political and Economic Risk Consultant (PERC), kualitas pendidikan di Indonesia berada pada urutan ke-12 dari 12 negara di Asia. Posisi Indonesia berada di bawah Vietnam. Data yang dilaporkan The World Economic Forum Swedia (2000) Indonesia memiliki daya saing yang rendah yaitu hanya menduduki urutan ke 37 dari 57 negara yang disurvey di dunia. Laporan United Nation Development Program (UNDP) tahun 2005 mengungkapkan bahwa kualitas pendidikan di Indonesia menempati posisi ke-110 dari 117 negara.

Laporan UNDP dan PERC tersebut mengindikasikan bahwa kualitas pendidikan di Indonesia masih relatif rendah, hal ini membuktikan bahwasannya masih banyak yang perlu diperbaiki baik dari segi kebijakan (undang-undang dan peraturan pemerintah) maupun segi pelaksanaan yang hari ini masih dengan pengawasannya yang tidak cukup ketat bahkan cenderung 'lepas tangan'.

Upaya peningkatan kualitas pendidikan bukan merupakan masalah yang sederhana, tetapi memerlukan penanganan yang multidimensi dengan melibatkan berbagai pihak yang terlibat. Dalam konteks ini, kualitas pendidikan bukan hanya terpusat pada pencapaian target kurikulum semata, akan tetapi menyangkut semua aspek yang secara langsung maupun tidak, turut menunjang terciptanya manusia-manusia seutuhnya. 
Peran serta masyarakat menjadi isu penting dalam Undang-Undang Sisdiknas No. 20 tahun 2003, sebuah kebijakan yang melibatkan masyarakat dalam program pendidikan serta lahirnya sebuah tawaran manajemen berbasis sekolah (SBM) yang memberi otonomi relatif luas kepada sekolah dan masyarakat. Pada Bab III pasal 8 dinyatakan bahwa "masyarakat berhak untuk berperan serta dalam perencanaan, pelaksanaan, pengawasan dan evaluasi program pendidikan". Ini menandakan bahwa eksistensi dan partisipasi masyarakat semakin diakui dan dibutuhkan dalam pembangunan dan pengembangan pendidikan khususnya pendidikan Islam.

Keikutsertaan dan kesadaran masyarakat untuk memikul tanggung jawab pendidikan bukan sekedar harapan tetapi merupakan suatu tuntutan mendesak yang harus diwujudkan dalam kegiatan-kegiatan nyata di lapangan. Partisipasi masyarakat dalam pendidikan, baik dalam lingkup masyarakat kecil maupun dalam skala yang lebih luas sebenarnya telah ada sejak dulu, yang tercermin dalam berbagai bentuk dan ekspresi di masyarakat.

Partisipasi adalah sebuah sikap yang mencirikan masyarakat dinamis. Conyears, mengidentifikasikan tiga kebutuhan dasar dalam pembangunan masyarakat, salah satu diantaranya adalah partisipasi dalam membuat dan melaksanakan program, selain kebutuhan dasar lainnya seperti pangan, sandang dan papan, kemudian pendidikan, kesehatan dan air bersih. Dalam hal ini manajemen menjadi tugas penyelenggara dan pengelola pendidikan yakni pemerintah dan sekolah. Karenanya sekolah sebagai lembaga formal penyelenggara pendidikan harus terus berupaya memelihara (maintenance) partisipasi masyarakat dengan menerapkan konsep manajemen yang baik dengan tawaran-tawaran program yang mampu menarik simpati dan menggugah gairahnya untuk berpartisipasi dan tentu saja program tersebut dapat menjawab tuntutan dan memenuhi kebutuhan masyarakat secara signifikan.

MTs Muhammadiyah 3 Al Furqon Banjarmasin merupakan salah satu lembaga pendidikan Muhammadiyah di kota Banjarmasin yang telah berdiri sejak tahun 2005. Dalam kurun waktu yang tidak terlalu lama tersebut, madrasah yang berlokasi di jalan Cemara Ujung No. 37 Rt. 51 Kecamatan Banjarmasin Utara ini telah mengalami perkembangan yang cukup pesat. Hal ini terlihat dari jumlah siswa yang masuk dan lulus setiap tahunnya mengalami peningkatan yang signifikan. Di samping itu, madrasah ini juga memiliki segudang prestasi yang telah diraih siswa dalam berbagai even perlombaan baik tingkat kota Banjarmasin maupun propinsi Kalimantan Selatan dengan meraih juara umum, serta juara 1 hingga juara harapan 2. Dari segi sarana prasarana, madrasah ini juga sangat mendukung terciptanya pembelajaran yang efektif dan efisien, diantaranya tersedianya ruang belajar yang representatif, ruang keterampilan, perpustakaan, laboratorium IPA dan komputer, serta berbagai sarana prasarana penunjang lainnya.

Semua hal tersebut di atas, tentu tidak terlepas dari tingginya partisipasi masyarakat dalam memajukan pendidikan di madrasah yang berdiri di atas tanah seluas $6060 \mathrm{~m}^{2}$ dengan status milik sendiri ini.

\section{LANDASAN TEORI}

Bentuk-Bentuk Partisipasi Masyarakat dalam Pendidikan

MTs Muhammadiyah 3 Al Furqon Banjarmasin merupakan lembaga 
pendidikan swasta yang dikelola organisasi Muhammadiyah, dalam hal ini di bawah naungan Pimpinan Cabang Muhammadiyah Banjarmasin 3. Dalam struktur organisasi Pimpinan Cabang Muhammadiyah Banjarmasin 3 terdiri dari berbagai majelis, salah satunya adalah Majelis Pendidikan Dasar dan Menengah (Dikdasmen) yang membidangi bidang pendidikan tingkat dasar dan menengah. Keberadaan Majelis Pendidikan Dasar dan Menengah (Dikdasmen) ada mulai tingkat pimpinan pusat, pimpinan wilayah, pimpinan daerah hingga tingkat pimpinan cabang.

MTs Muhammadiyah 3 Al Furqon Banjarmasin yang beralamat di jalan Cemara Ujung No. 37 Rt. 51 Kecamatan Banjarmasin Utara ini berada dalam satu komplek dengan MA Muhammadiyah Al Furqon dan SMK Muhammadiyah Farmasi Al Furqon Banjarmasin. Dalam pengelolaannya berada di bawah koordinasi Direktur Pondok Pesantren Modern Muhammadiyah Al Furqon Banjarmasin yakni Bapak Drs. H. Murhan Zuhri, M.Ag. Keberadaan Direktur Pondok Pesantren Modern Muhammadiyah Al Furqon Banjarmasin ini merupakan kelanjutan dari peran Majelis Pendidikan Dasar dan Menengah (Dikdasmen) Muhammadiyah Cabang Banjarmasin 3.

Sekolah/madrasah yang berada di bawah naungan Direktur Pondok Pesantren Modern Muhammadiyah Al Furqon Banjarmasin ini juga memiliki struktur lainnya yakni komite madrasah yang dipimpin Bapak Ir. H. Anwar Effendi. Keberadaan komite madrasah ini dibentuk sebagaimana yang dipersyaratkan oleh pemerintah sebagai prasyarat mutlak bagi implementasi manajemen berbasis madrasah (MBM) yang efektif dan efisien. Komite Madrasah merupakan badan mandiri yang mewadahi peran serta masyarakat dalam rangka meningkatkan mutu, pemerataan, dan efisiensi pengelolaan pendidikan di satuan pendidikan madrasah, baik pada pendidikan prasekolah maupun pendidikan dasar dan menengah sehingga terwujudnya demokratisasi, transparansi dan akuntabilitas dalam penyelenggaraan pendidikan.

Pembentukan dan pengangkatan pengurus komite madrasah pada MTs Muhammadiyah 3 Al Furqon Banjarmasin dilakukan dengan melibatkan seluruh komponen warga sekolah (stake holder) mulai dari kepala madrasah, wakil kepala madrasah, guru, karyawan, orang tua siswa dan masyarakat umum lainnya yang mempunyai komitmen tinggi terhadap dunia pendidikan khususnya pendidikan Muhammadiyah.

Peran yang telah dijalankan Komite Madrasah bersama Direktur Pondok Pesantren Modern Muhammadiyah Al Furqon Banjarmasin dan Majelis Dikdasmen Muhammadiyah Cabang Banjarmasin 3 adalah sebagai berikut:

1. Pemberi pertimbangan (advisory agency) dalam penentuan dan pelaksanaan kebijakan pendidikan pada MTs Muhammadiyah 3 Al Furqon Banjarmasin;

2. Pendukung (supporting agency), baik yang berwujud finansial, pemikiran, maupun tenaga dalam penyelenggaraan pendidikan pada MTs Muhammadiyah 3 Al Furqon Banjarmasin;

3. Pengontrol (controlling agency) dalam rangka transparansi dan akuntabilitas penyelenggaraan pendidikan pada MTs Muhammadiyah $3 \mathrm{Al}$ Furqon Banjarmasin; dan

4. Mediator antara pemerintah (executive) dengan masyarakat pada MTs Muhammadiyah 3 Al Furqon Banjarmasin. 
Untuk menjalankan perannya, Komite Madrasah bersama Direktur Pondok Pesantren Modern Muhammadiyah Al Furqon Banjarmasin dan Majelis Dikdasmen Muhammadiyah Cabang Banjarmasin 3 memiliki beberapa fungsi yang telah dijalankan sebagai berikut:

1. Mendorong tumbuhnya perhatian dan komitmen masyarakat terhadap penyelenggaraan pendidikan pada MTs Muhammadiyah 3 Al Furqon Banjarmasin yang lebih bermutu.

2. Melakukan kerjasama dengan masyarakat (perorangan/organisasi/dunia usaha/dunia industri) dan pemerintah berkenaan dengan penyelengga-raan pendidikan pada MTs Muhammadiyah 3 Al Furqon Banjarmasin yang bermutu.

3. Menampung dan menganalisis aspirasi, ide, tuntutan dan berbagai kebutuhan pendidikan pada MTs Muhammadiyah 3 Al Furqon Banjarmasin yang diajukan oleh masyarakat.

4. Memberikan masukan, pertimbangan, dan rekomendasi kepada MTs Muhammadiyah 3 Al Furqon Banjarmasin mengenai:

a. Kebijakan dan program pendidikan;

b. Rencana Anggaran Pendidikan dan Belanja Madrasah (RAPBM);

c. Kriteria kinerja satuan pendidikan;

d. Kriteria tenaga kependidikan; dan

e. Hal-hal lain yang terkait dengan pendidikan.

5. Mendorong orang tua dan masyarakat berpartisipasi dalam pendidikan guna mendukung peningkatan mutu dan pemerataan pendidikan pada MTs Muhammadiyah 3 Al Furqon Banjarmasin.

6. Menggalang dana masyarakat dalam rangka pembiayaan penyeleng-garaan pendidikan pada MTs Muhammadiyah 3 Al Furqon Banjarmasin.

7. Melakukan evaluasi dan pengawasan terhadap kebijakan, program, penyelenggaraan, dan keluaran pendidikan pada MTs Muhammadiyah $3 \mathrm{Al}$ Furqon Banjarmasin.

Komite Madrasah sesuai dengan peran dan fungsinya bersama Direktur Pondok Pesantren Modern Muhammadiyah Al Furqon Banjarmasin dan Majelis Dikdasmen Muhammadiyah Cabang Banjarmasin 3, melakukan akuntabilitas sebagai berikut:

1. Menyampaikan hasil kajian pelaksanaan program madrasah kepada stakeholder secara periodik, baik yang berupa keberhasilan maupun kegagalan dalam pencapaian tujuan dan sasaran program madrasah.

2. Menyampaikan laporan pertanggungjawaban bantuan masyarakat baik berupa materi (dana, barang tak bergerak maupun bergerak), maupun non materi (tenaga, pikiran) kepada masyarakat dan pemerintah setempat.

Proses pemilihan dan pengangkatan Kepala MTs Muhammadiyah $3 \mathrm{Al}$ Furqon Banjarmasin dilakukan berdasarkan penilaian dan pengamatan Direktur Pondok Pesantren Modern Muhammadiyah Al Furqon Banjarmasin dan Majelis Dikdasmen Muhammadiyah Cabang Banjarmasin 3 untuk diusulkan Pimpinan Cabang Muhammadiyah Banjarmasin 3 ke tingkat Daerah. Nama kepala madrasah yang diusulkan tersebut kemudian ditetapkan melalui surat keputusan (SK) oleh Pimpinan Daerah Muhammadiyah Kota Banjarmasin.

Penilaian dan pengamatan Direktur Pondok Pesantren Modern 
Muhammadiyah Al Furqon Banjarmasin dan Majelis Dikdasmen Muhammadiyah Cabang Banjarmasin

3 terhadap kepala sekolah yang akan dipilih didasarkan atas beberapa pendekatan. Yakni: a) pendekatan ideologis: hendaknya memahami visi, misi dan hakikat perjuangan Muhammadiyah; sudah berpengalaman menjadi guru di sekolah Muhammadiyah dan sudah memiliki KTAM; b) pendekatan paradigmatik; bisa memahami dan menafsirkan maksud dan tujuan Muhammadiyah; tidak terlena dengan kesuksesan masa lalu; mampu menafsirkan visi, misi dan tujuan Muhammadiyah; c) pendekatan profesionalisme; mampu melakukan reformasi manajemen dari manajemen konvensional menuju manajemen mutu terpadu serta d) pendekatan pengembangan; mempunyai pemahaman yang sama dengan Direktur Pondok Pesantren Modern Muhammadiyah Al Furqon Banjarmasin dan Majelis Dikdasmen Muhammadiyah Cabang Banjarmasin 3 untuk mengembangkan lembaga pendidikan ini.

Dalam proses penentuan kebijakan yang dilakukan kepala MTs Muhammadiyah 3 Al Furqon Banjarmasin mengacu kepada ketentuan yang telah ditetapkan Kementerian Agama RI ditambah dengan ketentuan khusus lainnya pada lembaga pendidikan Muhammadiyah. Misalnya pada aspek kurikulum, selain mengacu pada kurikulum yang dicanangkan pemerintah juga diperkaya dengan kurikulum khusus pada aspek keIslaman dan kemuhammadiyahan.

Dalam rangka meningkatkan mutu pendidikan dan mengoptimalkan layanan kepada masyarakat serta menumbuh-kembangkan budaya demokrasi pada MTs Muhammadiyah 3 Al Furqon Banjarmasin ini. Yakni upaya kepala madrasah untuk melibatkan semua komponen dalam forum komite madrasah baik guru, orang tua, maupun masyarakat lainnya dalam beberapa kebijakan yang diambil. Di samping itu kepala madrasah senantiasa menjalin komunikasi yang kondusif dan harmonisasi antar unsur-unsur pendidikan pada MTs Muhammadiyah 3 Al Furqon Banjarmasin untuk terwujudnya transparansi dan akuntabilitas sekolah/madrasah.

Keterlibatan semua komponen sekolah dalam penentuan kebijakan pada MTs Muhammadiyah 3 Al Furqon Banjarmasin dapat dilihat dalam penentuan kebijakan masalah keuangan. Sebelum menentukan kebijakan masalah keuangan, pihak Direktur Pondok Pesantern Modern Muhammadiyah Al Furqon Banjarmasin, Pimpinan Cabang Muhammadiyah Banjarmasin 3 serta komite madrasah terlebih dahulu mendiskusikannya dengan berbagai komponen lainnya. Di samping itu, pelibatan komponen sekolah dalam menentukan kebijakan juga dapat dilihat dari keterlibatan mereka dalam merencanakan pengembangan minat siswa. Begitu juga halnya dengan pengadaan fasilitas atau sarana pendidikan pada MTs Muhammadiyah 3 Al Furqon Banjarmasin semua komponen sekolah dilibatkan, sebelum sarana atau fasilitas itu diadakan terlebih dahulu dibicarakan (didiskusikan) dengan berbagai komponen yang ada. Pelibatan semua komponen sekolah pada MTs Muhammadiyah 3 Al Furqon Banjarmasin juga dapat dilihat dari pelaksanaan evaluasi sekolah. Pihak sekolah senantiasa melibatkan mereka agar dapat menjiwai setiap penilaian yang dilakukan dan dapat memberikan alternatif pemecahan.

Walaupun demikian, tidak semua kebijakan yang diambil pihak MTs Muhammadiyah 3 Al Furqon Banjarmasin melibatkan semua komponen 
sekolah. Terutama dalam hal rekrutmen tenaga pendidik dan tenaga kependidikan menjadi kewenangan Direktur Pondok Pesantren Modern Muhammadiyah Al Furqon Banjarmasin bersama kepala MTs Muhammadiyah 3 Al Furqon Banjarmasin. Hal ini dilakukan dalam rangka menjamin agar tenaga pendidik dan tenaga kependidikan yang direkrut nantinya memiliki kesamaan visi dan misi dengan lembaga pendidikan Muhammadiyah. Terutama tenaga pendidik yang akan mengajar mata pelajaran keIslaman harus sesuai dengan pemahaman yang diyakini Muhammadiyah. Walaupun dalam kenyataannya, juga terdapat beberapa guru yang diperbantukan pemerintah (guru PNS) pada MTs Muhammadiyah 3 Al Furqon Banjarmasin yang memiliki pemahaman yang berbeda dengan paham Muhammadiyah, tetapi tidak sampai menimbulkan keresahan di kalangan orang tua siswa. Untuk menyamakan persepsi tersebut, pihak Direktur Pondok Pesantren Modern Muhammadiyah Al Furqon Banjarmasin dan Majelis Dikdasmen Muhammadiyah Cabang Banjarmasin 3 senantiasa melakukan pendekatan dengan guru yang bersangkutan agar dapat menyesuaikan diri agar sejalan dengan visi dan misi lembaga pendidikan Muhammadiyah, lewat berbagai pengajian keIslaman dan Kemuhammadiyahan baik yang disampaikan oleh Pimpinan Wilayah Muhammadiyah Kalimantan Selatan maupun Pimpinan Daerah Muhammadiyah Kota Banjarmasin.

Suasana sekolah baik fisik maupun psikologis merupakan prasyarat utama terlaksananya suatu proses belajar mengajar secara optimal. Iklim sekolah yang kondusif memberikan perlindungan kepada siswa dan warga sekolah lainnya untuk melaksanakan pendidikan sesuai dengan target rencana yang ditetapkan. Menyadari hal ini, maka MTs Muhammadiyah 3 Al Furqon Banjarmasin mencoba membangun suasana kebersamaan dan kekeluargaan diantara warga sekolah. Suasana kebersamaan pada MTs Muhammadiyah 3A1 Furqon Banjarmasin dapat dilihat dari komunikasi dan interaksi yang terjalin antara kepala madrasah, guru, karyawan dan siswa. Kebersamaan lainnya pada MTs Muhammadiyah 3 Al Furqon Banjarmasin juga dapat dilihat pada manajemen kolektif, dimana masing-masing anggota komponen sekolah merasa dihargai dan memiliki tanggung jawab bersama dalam pendidikan pada MTs Muhammadiyah 3 Al Furqon Banjarmasin.

Demikian halnya dalam rangka menjalin kebersamaan dan kekeluargaan bagi MTs Muhammadiyah 3 Al Furqon Banjarmasin, dimana siswa tidak diposisikan sebagai suatu objek yang pasif, melainkan sebagai individu yang membutuhkan bantuan dalam mencapai kedewasaannya. Oleh karenanya, guru bukanlah orang berkuasa yang mampu memerintah dan menghukum secara sewenang-wenang, sementara di sisi lain siswa harus patuh, tunduk dan taat pada gurunya. Komunikasi yang dibangun pada MTs Muhammadiyah 3 Al Furqon Banjarmasin, tidak hanya antar guru, karyawan, siswa dan kepala madrasah saja, tetapi juga dengan lingkungan sekolah, orang tua siswa dan masyarakat umum lainnya.

Untuk meningkatkan kualitas pendidikan dan pelayanan kepada semua warga sekolah, MTs Muhammadiyah 3 Al Furqon Banjarmasin membuka kebebasan akademis bagi seluruh warga sekolah. Hal ini diakui beberapa guru, bahwa pihak sekolah memberikan kebebasan pada guru dan karyawan untuk mengikuti berbagai pelatihan, pendidikan serta pengembangan bakat sesuai dengan kebutuhan individualnya masing-masing. 
MTs Muhammadiyah 3 Al Furqon Banjarmasin sebagai lembaga pendidikan yang keberadaannya tidak terlepas dari dukungan dan upaya masyarakat, menjadikan masyarakat sebagai induk dan merupakan bagian yang tidak terpisahkan dari semua proses penyelenggaraan pendidikan. Masyarakat bagi MTs Muhammadiyah 3 Al Furqon Banjarmasin merupakan sumber daya yang sangat bermanfaat dan bermakna bagi proses belajar mengajar.

Terhadap partisipasi masyarakat dengan berbagai bentuknya, MTs Muhammadiyah 3 Al Furqon Banjarmasin mempunyai cara dan bentuk yang berbeda dalam merespon partisipasi mereka sesuai dengan bentuk dan partisipasinya. Kaitannya dengan partisipasi masyarakat, MTs Muhammadiyah 3 Al Furqon Banjarmasin menjadi fasilitator bagi pertemuan orang tua siswa dengan pengurus komite madrasah dan Direktur Ponpes Modern Muhammadiyah Al Furqon Banjarmasin. Di samping itu, MTs Muhammadiyah 3 Al Furqon Banjarmasin juga memberikan kebebasan kepada anggota masyarakat untuk mengeluarkan gagasan, ide, dan harapan-harapan mereka.

Desentralisasi pendidikan menuntut adanya transparansi dan akuntabilitas atau pertanggung jawaban sekolah terhadap kegiatan dan hasil pendidikan yang telah dicapai. Telah menjadi pengetahuan umum bahwa manajemen sekolah khususnya yang berkaitan dengan perencanaan penggunaan biaya pendidikan amat tertutup. Hanya kepala sekolah/ madrasah dan bendaharawan saja yang mengetahui berapa besar dana yang dihimpun, dan hanya mereka juga yang mengetahui untuk apa dana tersebut dibelanjakan dan dipertanggung jawabkan.

\section{Strategi dan pendekatan dalam Rangka Membina dan Menumbuh kembangkan Partisipasi Masyarakat Dalam Pendidikan}

Sebagaimana diketahui bahwa timbulnya partisipasi masyarakat dalam pendidikan tidak terjadi dengan sendirinya, melainkan melalui sebuah proses dan tahapan-tahapan tertentu. Proses dan tahapan tersebut harus sesuai dengan latar belakang sosial dan budaya dari masyarakat setempat.

Langkah-langkah strategis dan pendekatan yang dilakukan dalam rangka membina dan menumbuhkembangkan partisipasi masyarakat dalam pendidikan pada MTs Muhammadiyah 3 Al Furqon Banjarmasin sebagai berikut:

\section{Identifikasi Masalah}

Dalam rangka penelaahan dan proses identifikasi terhadap permasalahanpermasalahan yang dihadapi kaitannya dengan partisipasi masyarakat dalam pendidikan pada MTs Muhammadiyah 3 Al Furqon Banjarmasin, merujuk pada nilai-nilai yang ada berkembang di tengah masyarakat itu sendiri. Diantaranya latar belakang budaya masyarakat setempat, latar belakang pendidikan masyarakat, keadaan sosial budaya, ekonomi, nilai-nilai keagamaan yang berlaku di tengah-tengah masyarakat.

Hasil identifikasi yang telah dilakukan, terdapat beberapa permasalahan yang perlu diperhatikan. Keadaan sosial budaya masyarakat setempat tidak terlalu heterogen, bahkan cenderung homogen. Budaya gotong royong masih dijunjung tinggi, sesuai dengan slogan masyarakat hidup rukun saling mengayomi, saling membantu dan mengasihi, senasib dan sepenanggungan. Namun demikian, kepatuhan mereka terhadap pimpinan (tokoh) masih kental. Nilai yang dipegang dan dijunjung tinggi pada masyarakat sekitar MTs Muhammadiyah 3 
Al Furqon Banjarmasin adalah nilai agama, sehingga dapat dikatakan bahwa masyarakat cukup agamis.

Permasalahan lain yang berhasil diidentifikasi adalah berkaitan dengan latar belakang pendidikan masyarakat. Pendidikan masyarakat terutama pendidikan orang tua siswa pada MTs Muhammadiyah 3 Al Furqon Banjarmasin bervariasi mulai dari SLTA sederajat hingga perguruan tinggi (PT). Tingkat pendidikan masyarakat tersebut juga sedikit banyaknya berpengaruh terhadap persepsi dan bentuk partisipasinya dalam pendidikan pada MTs Muhammadiyah 3 Al Furqon Banjarmasin. Latar belakang sosial ekonomi orang tua siswa pada MTs Muhammadiyah 3 Al Furqon Banjarmasin beragam. Diantara mereka ada yang berprofesi sebagai PNS, TNI, Polri, pegawai instansi swasta, tenaga medis, pegawai BUMN dan lain sebagainya. Hal ini tentu berpengaruh pada intensifikasi dan bentuk partisipasi mereka dalam pendidikan pada MTs Muhammadiyah 3 Al Furqon Banjarmasin.

\section{Perlakuan dan Pendekatan}

Proses selanjutnya setelah identifikasi masalah adalah pemberian perlakuan dengan pendekatan-pendekatan yang sesuai dengan situasi dan kondisi masingmasing. Demikian pula yang dilakukan MTs Muhammadiyah 3 Al Furqon Banjarmasin, terdapat beberapa bentuk perlakuan yang dilakukan untuk meningkatkan partisipasi masyarakat dalam pendidikan pada MTs Muhammadiyah 3 Al Furqon Banjarmasin.

Melihat realitas yang masyarakat yang agamis, maka upaya MTs Muhammadiyah 3 Al Furqon Banjarmasin dalam mengajak masyarakat untuk lebih terlibat dan berpartisipasi dalam pendidikan melalui pendekatan keagamaan. Salah satu media yang dipakai oleh MTs Muhammadiyah 3 Al Furqon Banjarmasin adalah pengajian keagamaan yang diadakan di lingkungan Pondok Pesantren Modern Muhamamdiyah Al Furqon Banjarmasin dengan menghadirkan tokohtokoh agama terkemuka. Dijelaskan pula pendekatan lain yang sering digunakan adalah melalui kegiatan pengajian keagamaan yang dilakukan pimpinan Pondok Pesantren Modern Muhamamdiyah Al Furqon Banjarmasin secara individual sebagai da'i, khatib ataupun penceramah pada masjid-masjid di lingkungan Muhammadiyah Kota Banjarmasin.

Melalui pendekatan kegamaan tersebut, dijelaskan tentang visi dan misi MTs Muhammadiyah 3 Al Furqon Banjarmasin yang berada di bawah naungan Pondok Pesantren Modern Muhamamdiyah Al Furqon Banjarmasin tersebut. Dijelaskan pula keberadaan lembaga pendidikan dapat berkembang pesat seiring dengan meningkatknya peran serta masyarakat untuk menunjang keberlangsungannya. Partisipasi masyarakat dalam pendidikan pada lembaga pendidikan swasta merupakan kebutuhan mutlak, di samping itu pendidikan juga merupakan tanggung jawab masyarakat dalam mengembangkannya. Keberadaan masyarakat dalam dunia pendidikan menjadi sangat penting, karena pendidikan lahir di tengah-tengah masyarakat dan lulusannya juga akan kembali ke tengah-tengah masyarakat.

Bentuk lain yang dilakukan MTs Muhammadiyah 3 Al Furqon Banjarmasin adalah memberikan peran aktif bagi tokoh agama maupun tokoh masyarakat dalam kepengurusan komite madrasah. Dengan demikian, diharapkan seluruh aspirasi masyarakat dan kebutuhan penyelenggaraan pendidikan dapat dengan mudah 
tersosialisasi dan dapat diterima oleh masyarakat. Di samping itu kebijakankebijakan yang diambil pihak MTs Muhammadiyah 3 Al Furqon Banjarmasin diharapkan dapat mengakomodasikan kebutuhan dan aspirasi masyarakat.

Hasil identifikasi yang dilakukan oleh MTs Muhammadiyah 3Al Furqon Banjarmasin, ada sebagian anggota masyarakat yang belum mengetahui atau belum sampai kepada mereka informasi atau pengetahuan tentang konsepsi dasar partisipasi masyarakat. MTs Muhammadiyah 3 Al Furqon Banjarmasin memberikan informasi kepada mereka dengan jelas disertai dengan contoh-contoh konkrit. Informasi yang selama ini dilakukan melalui penyuluhan, ceramahceramah, serta kunjungan ke rumah-rumah masyarakat. Bagi masyarakat yang sudah mengetahui arti penting partisipasi masyarakat dan konsepsi partisipasi masyarakat dalam pendidikan, maka upaya yang dilakukan kepada mereka adalah melibatkan mereka dalam acara-acara khusus seperti seminar, dialog dan sebagainya.

\section{Pembinaan}

Partisipasi masyarakat dalam pendidikan merupakan instrument vital dalam penyelenggaraan pendidikan. Oleh karena itu, perlu adanya upaya pembinaan yang terencana dan dilaksanakan secara terus menerus terhadap masyarakat baik secara individual maupun secara kolektif. Dengan demikian, diharapkan keterlibatan masyarakat dalam keseluruhan proses pendidikan melembaga menjadi sebuah kultur kehidupan masyarakat.

Kaitannya dengan upaya melembagakan atau membudayakan partisipasi masyarakat, maka perlu dikaji dan dicermati partisipasi masyarakat tersebut sehingga benar-benar menjadi sebuah kebutuhan, bukan sekedar aktivitas yang temporal. Menyadari hal ini, MTs Muhammadiyah 3 Al Furqon Banjarmasin mencoba mengambil langkah-langkah yang diharapkan dapat melembagakan dan membudayakan partisipasi masyarakat dalam pendidikan. Diharapkan partisipasi masyarakat dalam pendidikan pada MTs Muhammadiyah $3 \mathrm{Al}$ Furqon Banjarmasin terus terjaga, terbina, senantiasa meningkat baik dari aspek kuantitas maupun kualitasnya.

Pembinaan partisipasi masyarakat dalam pendidikan dilakukan melalui pertemuan komite madrasah. Selama ini masih banyak anggapan di masyarakat bahwa komite madrasah merupakan perkumpulan orang tua yang hanya bertugas pengumpul dana bagi sekolah/ madrasah. Sebagian mereka beranggapan, apabila mendapatkan undangan pertemuan komite, maka yang terbayang dibenak mereka selalu dikaitkan dengan pendanaan dan kegiatan pembangunan sekolah/madrasah. Oleh karenanya ada keengganan mereka untuk menghadiri pertemuan komite madrasah.

Menyadari hal tersebut, pihak MTs Muhammadiyah 3 Al Furqon Banjarmasin mencoba memprogramkan pertemuan anggota komite madrasah secara berkala dan rutin yaitu 4 bulan sekali. Melalui pertemuan ini diharapkan tidak hanya membahas masalah pendanaan saja tetapi semua aspek penyelenggaraan pendidikan pada MTs Muhammadiyah 3 Al Furqon Banjarmasin. Dalam acara ini seluruh anggota komite madrasah diberikan kebebasan untuk menyampaikan pendapat, gagasan, kritikan, saran bahkan keberatankeberatannya terhadap penyelenggaraan pendidikan pada MTs Muhammadiyah $3 \mathrm{Al}$ Furqon Banjarmasin. Diharapkan jika pertemuan rutin ini dapat terlaksana, maka 
partisipasi masyarakat dalam pendidikan pada MTs Muhammadiyah 3 Al Furqon Banjarmasin tetap terjaga, terpantau dan semakin meningkat.

\section{Analisis Data}

Pendidikan sebagai tanggung jawab bersama antara pemerintah, orang tua dan masyarakat telah dimaklumi, walaupun penjabaran secara operasional tidak mudah memperoleh kesepakatan diantara pihak-pihak yang berkepentingan (stakeholder). Pada saat anak diserahkan ke sekolah/madrasah dengan harapan anak tersebut memperoleh pelayanan pendidikan bagi pertumbuhan dan perkembangan mereka, sekolah/madrasah diharapkan menyediakan pelayanan terbaik bagi mereka. Sementara itu, kelompok- kelompok masyarakat dengan ragam dan tingkatannya juga menghadirkan harapan- harapan serupa.

Pemerintah atas nama negara telah merumuskan kebijakan-kebijakan dan harapan- harapan, ketentuan-ketentuan dan prosedur operasional pendidikan. Secara singkat, dapat dikatakan bahwa sekolah/madrasah dirancang agar menyediakan pelayanan pendidikan secara optimal bagi anak (siswa), dan masyarakat agar tujuan pendidikan nasional yang telah ditetapkan pemerintah agar terwujud. Banyak harapan dari berbagai kepentingan tadi, menimbulkan permasalahan mengenai penyediaan pelayanan yang efektif bagi sekolah/ madrasah. Sekolah/madrasah akan mengalami kesulitan mengakomodasikan berbagai tuntutan baik jenis dan kualifikasinya. Tanpa dukungan pihak-pihak di luar sekolah/ madrasah, usaha mengakomodasikan berbagai harapan yang sarat dengan kepentingan tersebut secara terpadu akan mengalami kesulitan. Hal demikian akan mempengaruhi kualitas layanan pendidikan dari luar sekolah (masyarakat) bagi layanan pendidikan di suatu sekolah/madrasah yang saat ini sangat diperlukan.

Sekolah/madrasah sebagai institusi sosial tumbuh dan berkembang oleh alasan- alasan sosial dan di dalamnya memiliki komponen-komponen dan ciri sosial. Sekolah/ madrasah dipengaruhi oleh dan mempengaruhi masyarakat penggunanya dalam batas- batas relatif. Pengaruh sekolah/madrasah akan optimal terhadap masyarakat apabila keterlibatan masyarakat (partisipasi) masyarakat dalam pendidikan di sekolah/madrasah menjadi optimal. Partisipasi birokratik berupa keterlibatan dalam mengambil keputusan, dukungan beraneka ragam, kemudahan dan peluang, dukungan jasa, dukungan finansial yang kesemuanya akan berpengaruh terhadap kualitas layanan pendidikan dan kualitas sekolah/madrasah dalam mengemban tugas yang dipikulnya.

\section{Bentuk-Bentuk Partisipasi Masyarakat dalam Pendidikan}

Sebagaimana diketahui bahwa partisipasi masyarakat dalam pendidikan dapat terwujud dalam berbagai pendekatan dan bentuk, sesuai dengan kondisi sosio-kultural masyarakat itu sendiri. Bentuk partisipasi masyarakat tersebut berupa pemberian sumbangan/bantuan material, tenaga, pemikiran maupun gagasan. Semakin maju lingkungan masyarakatnya, maka bentuk partisipasinya cenderung pada sumbangan non fisik, berupa sumbangan pemikiran/gagasan selain materi dan tenaga.

Bentuk-bentuk partisipasi masyarakat dalam pendidikan pada MTs Muhammadiyah 3 Al Furqon Banjarmasin sebagai berikut: 


\section{Partisipasi sebagai Pengurus Komite Madrasah}

Komite Madrasah merupakan badan mandiri yang mewadahi peran serta masyarakat dalam rangka meningkatkan mutu, pemerataan, dan efisiensi pengelolaan pendidikan di satuan pendidikan madrasah, baik pada pendidikan prasekolah maupun pendidikan dasar dan menengah sehingga terwujudnya demokratisasi, transparansi dan akuntabilitas dalam penyelenggaraan pendidikan.

Dalam kenyataannya, bahwa komite madrasah pada MTs Muhammadiyah 3 Al Furqon Banjarmasin diisi oleh berbagai komponen masyarakat mulai dari orang tua siswa, tokoh agama, tokoh masyarakat dan berbagai pihak lainnya yang mempunyai perhatian khusus terhadap perkembangan pendidikan Muhammadiyah. Salah satu indikator adanya partisipasi masyarakat dalam hal ini yakni kehadiran pengurus dalam berbagai rapat/ pertemuan sekolah. Walaupun diakui bahwa tingkat kehadirannya belum bisa maksimal dengan berbagai macam alasan. Di samping itu mereka juga senantiasa berpartisipasi aktif dalam memberikan masukan, saran, ide maupun sumbangan yang bersifat fisik (material).

Peran yang telah dijalankan Komite Madrasah bersama Direktur Pondok Pesantren Modern Muhammadiyah Al Furqon Banjarmasin dan Majelis Dikdasmen Muhammadiyah Cabang Banjarmasin 3 adalah sebagai berikut:

1. Pemberi pertimbangan (advisory agency) dalam penentuan dan pelaksanaan kebijakan pendidikan pada MTs Muhammadiyah 3 Al Furqon Banjarmasin;

2. Pendukung (supporting agency), baik yang berwujud finansial, pemikiran, maupun tenaga dalam penyelenggaraan pendidikan pada MTs Muhammadiyah 3 Al Furqon Banjarmasin;

3. Pengontrol (controlling agency) dalam rangka transparansi dan akuntabilitas penyelenggaraan pendidikan pada MTs Muhammadiyah $3 \mathrm{Al}$ Furqon Banjarmasin; dan

4. Mediator antara pemerintah(executive)denganmasyarakatpadaMTsMuhammadiyah $3 \mathrm{Al}$ Furqon Banjarmasin.

Berdasarkan temuan di atas, peran yang telah dijalankan sebagian masyarakat baik secara individual maupun institusional yang tergabung dalam komite madrasah dapat dikatakan telah memenuhi unsur manajemen partisipatif. Dimana dalam proses manajemen terdapat fungsi-fungsi pokok yang harus diambil yaitu: perencanaan (planning), pengorganisasian (organizing), pemimpin (leading), dan pengawasan (controlling). Dalam konteks ini, dapat dikatakan bahwa partisipasi masyarakat dalam pendidikan pada MTs Muhammadiyah 3 Al Furqon Banjarmasin telah berjalan dengan baik. Bentukbentuk partisipasi tersebut sesuai dengan pendapat yang dikemukakan Konkon sebagai berikut:

1. Sumbangan tenaga fisik;

2. Sumbangan finansial;

3. Sumbangan material;

4. Sumbangan moral (nasehat, petuah, amanat); dan

5. Sumbangan keputusan

Hal serupa juga dikemukakan Depdiknas yang meliputi:

1. Pendirian 
2. Pengadaan

3. Pemberian bantuan tentang: tenaga kependidikan, pengajaran, bimbingan, tenaga ahli, dana, gedung, tanah, buku, magang kerja, manajemen, pemikiran dan penelitian.

Dengan demikian dapat disimpulkan bahwa partisipasi masyarakat dalam pendidikan pada MTs Muhammadiyah 3 Al Furqon Banjarmasin telah terwujud dalam bentuk keterlibatan mereka sebagai pengurus komite madrasah.

\section{Partisipasi Masyarakat dalam Kegiatan-Kegiatan Sekolah/Madrasah}

Bentuk partisipasi masyarakat dalam pendidikan pada MTs Muhammadiyah 3 Al Furqon Banjarmasin selain keterlibatan mereka sebagai pengurus komite madrasah, bentuk partisipasi lainnya dapat dilihat dari keterlibatan mereka pada berbagai macam kegiatan atau acara sekolah. Dalam kegiatan tersebut masyarakat sekitarnya baik secara institusional maupun individual senantiasa dilibatkan baik sebagai penanggung jawab maupun sebagai pendukung dalam kegiatan tersebut.

Dalam pelaksanaan kegiatan tertentu pihak MTs Muhammadiyah $3 \mathrm{Al}$ Furqon Banjarmasin juga senantiasa menggalang dukungan dari masyarakat luas pada umumnya dan orang tua siswa pada khususnya baik dalam bentuk material maupun non material. Bank Syariah Mandiri (BSM) sebagai salah satu perbankan syariah yang ada di kota Banjarmasin juga menjadi mitra kerja MTs Muhammadiyah 3 Al Furqon Banjarmasin. Partisipasi mereka dalam bentuk pemberian pemahaman mengenai pentingnya budaya menabung bagi siswa pada MTs Muhammadiyah 3 Al Furqon Banjarmasin, serta menyediakan counter khusus untuk melayani siswa yang akan menabung.

Berdasarkan temuan ini, telah terdapat beberapa "tools" (sarana/alat manajemen) pada MTs Muhammadiyah 3 Al Furqon Banjarmasin dalam rangka mencapai tujuan manajemen yang sebaik-baiknya. Seperti adanya men (manusia) yang siap berpartisipasi, adanya sumbangan material maupun non material yang diberikan oleh masyarakat serta berbagai sarana/alat manajemen lainnya.

Sarana/alat manajemen (tools of management) yang ada MTs Muhammadiyah 3 Al Furqon Banjarmasin ini selaras dengan teori yang dirumuskan dalam istilah $6 \mathrm{M}$, yakni:

1. Men (tenaga kerja manusia)

2. Money (dana yang diperlukan untuk proses kegiatan)

3. Methods (cara/sistem/teknik untuk mencapai tujuan)

4. Materials (bahan/benda yang diperlukan)

5. Machines (mesin-mesin yang diperlukan)

6. Market (pangsa pasar hasil produksi)

\section{Partisipasi Masyarakat dalam Menjaga Keamanan Sekolah/Madrasah}

Bentuk partisipasi masyarakat dalam pendidikan pada MTs Muhammadiyah 3 Al Furqon Banjarmasin lainnya adalah adanya keterlibatan masyarakat dalam menjaga keamanan sekolah/madrasah. Untuk mendukung ketertiban, keamanan dan disiplin siswa, MTs Muhammadiyah 3 Al Furqon Banjarmasin senantiasa mengoptimalkan peran serta masyarakat dalam menciptakan suasana kondusif bagi terlaksananya proses pembelajaran, serta 
memberikan kontrol sosial agar para siswa tidak melakukan tindakan asusila.

MTs Muhammadiyah 3 Al Furqon Banjarmasin juga bekerjasama dengan pihak kepolisian khususnya Polsek Banjarmasin Utara untuk memberikan pemahaman tentang ketertiban berlalu lintas dan pencegahan tindakan kriminal. Badan Narkotika Nasional (BNN) Propinsi Kalimantan Selatan juga diikutsertakan dalam pelaksanaan pendidikan pada MTs Muhammadiyah 3 Al Furqon Banjarmasin ini, yakni memberikan penyuluhan terkait penyalahgunaan obat-obat terlarang khususnya dikalangan anak muda.

Dengan demikian dapat disimpulkan bahwa keterlibatan masyarakat dalam pendidikan pada MTs Muhammadiyah 3 Al Furqon Banjarmasin tidak lagi diartikan secara sempit (tidak hanya terbatas pada pembiayaan, pendanaan fisik maupun materiil). Dalam konteks ini, keterlibatan masyarakat dalam keseluruhan proses menyebabkan mereka merasa memiliki dan bertanggung jawab sekaligus akan berpartisipasi aktif dalam upaya memelihara dan melestarikan, bahkan tidak menutup kemungkinan dalam skala tertentu masyarakat akan berperan aktif dalam memotivasi, membimbing, dan mengarahkan putra- putrinya dalam masalah pendidikan.

Hal tersebut di atas, sesuai dengan Peraturan Pemerintah (PP) No. 39 Tahun 1992 menyatakan bahwa partisipasi masyarakat dalam pendidikan dalam bentuk:

1. Pendirian dan penyelenggaraan satuan pendidikan pada jalur pendidikan sekolah atau jalur pendidikan luar sekolah pada semua jenjang pendidikan kecuali pendidikan kedinasan jalur pendidikan sekolah;

2. Pengadaan dan pemberian tenaga pendidikan;

3. Bantuan tenaga ahli;

4. Pengadaan dan pemberian bantuan yanag dapat berupa wakaf, hibah, sumbangan pinjaman, beasiswa dan bentuk-bentuk lain yang sejenis;

5. Pengadaan atau penyelenggaraan program pendidikan yang belum diselenggarakan oleh pemerintah;

6. Pengadaan dan bantuan buku pelajaran dan peralatan pendidikan untuk melaksanakan kegiatan belajar mengajar;

7. Pemberian kesempatan untuk magang dan atau latihan kerja;

8. Pengadaan dan bantuan ruangan gedung dan tanah untuk melaksanakan kegiatan belajar mengajar;

9. Bantuan manajemen bagi penyelenggaraan satuan pendidikan dan pengembangan pendidikan nasional;

10. Pemberian bantuan pemikiran dan pertimbangan berkenaan dengan penentuan kebijaksanaan dan atau penyelenggaraan pengembangan pendidikan;

11. Pemberian bantuan dan kerjasama dalam kegiatan penelitian dan pengembangan pendidikan;

12. Keikutsertaan dalam program pendidikan dan/atau penelitian yang diselenggarakan oleh pemerintah di dalam dan atau di luar negeri.

\section{Strategi dan pendekatan dalam Rangka Membina dan Menumbuhkembangkan Partisipasi Masyarakat Dalam Pendidikan}

Pengelolaan partisipasi masyarakat oleh sekolah sangat diperlukan karena pada dasarnya sekolah bukanlah suatu lembaga yang terpisah dari 
masyarakat. Sekolah merupakan lembaga yang bekerja dalam konteks sosial. Sekolah mengambil siswanya dari masyarakat setempat, sehingga eksistensinya tergantung dari dukungan sosial dan finansial dari masyarakat betatapun karyanya pemerintah dan atau yayasan penyelenggara. Oleh karena itu hubungan sekolah dan masyarakat merupakan salah satu komponen penting yang harus dikelola dalam kerangka penyelenggaraan pendidikan.

Pengaruh masyarakat terhadap eksistensi sekolah sebagai lembaga sosial terasa teramat kuat dan berpengaruh pula kepada para individu yang ada dalam lingkungan sekolah. Lingkungan sekolah merupakan masyarakat yang bersifat kompleks dan bersifat unik sebagai akibat latar belakang dimensi budaya yang beragam. Hasil temuan di lapangan, menunjukkan bahwa terdapat beberapa langkah- langkah strategis dan pendekatan yang telah dilakukan dalam rangka membina dan menumbuhkembangkan partisipasi masyarakat dalam pendidikan pada MTs Muhammadiyah 3 Al Furqon Banjarmasin sebagai berikut:

\section{Identifikasi Masalah}

Hasil identifikasi yang telah dilakukan, terdapat beberapa permasalahan yang perlu diperhatikan. Keadaan sosial budaya masyarakat setempat tidak terlalu heterogen, bahkan cenderung homogen. Budaya gotong royong masih dijunjung tinggi, sesuai dengan slogan masyarakat hidup rukun saling mengayomi, saling membantu dan mengasihi, senasib dan sepenanggungan.

Permasalahan lain yang berhasil diidentifikasi adalah berkaitan dengan latar belakang pendidikan masyarakat. Pendidikan masyarakat terutama pendidikan orang tua siswa pada MTs Muhammadiyah 3 Al Furqon Banjarmasin bervariasi mulai dari SLTA sederajat hingga perguruan tinggi (PT). Latar belakang sosial ekonomi orang tua siswa pada MTs Muhammadiyah $3 \mathrm{Al}$ Furqon Banjarmasin beragam.

\section{Perlakuan dan Pendekatan}

Melihat realitas yang masyarakat yang agamis, maka upaya MTs Muhammadiyah 3 Al Furqon Banjarmasin dalam mengajak masyarakat untuk lebih terlibat dan berpartisipasi dalam pendidikan melalui pendekatan keagamaan. Salah satu media yang dipakai oleh MTs Muhammadiyah 3 Al Furqon Banjarmasin adalah pengajian keagamaan yang diadakan di lingkungan Pondok Pesantren Modern Muhamamdiyah Al Furqon Banjarmasin dengan menghadirkan tokohtokoh agama terkemuka. Dijelaskan pula pendekatan lain yang sering digunakan adalah melalui kegiatan pengajian keagamaan yang dilakukan pimpinan Pondok Pesantren Modern Muhamamdiyah Al Furqon Banjarmasin secara individual sebagai da'i, khatib ataupun penceramah pada masjid-masjid di lingkungan Muhammadiyah kota Banjarmasin.

Bentuk lain yang dilakukan MTs Muhammadiyah 3 Al Furqon Banjarmasin adalah memberikan peran aktif bagi tokoh agama maupun tokoh masyarakat dalam kepengurusan komite madrasah. Hasil identifikasi yang dilakukan oleh MTs Muhammadiyah 3 Al Furqon Banjarmasin, ada sebagian anggota masyarakat yang belum mengetahui atau belum sampai kepada mereka informasi atau pengetahuan tentang konsepsi dasar partisipasi masyarakat. MTs Muhammadiyah 3 Al Furqon Banjarmasin memberikan informasi kepada mereka dengan jelas disertai dengan contoh-contoh konkrit. Informasi yang selama ini dilakukan melalui penyuluhan, ceramah-ceramah, serta kunjungan ke rumah-rumah masyarakat. 


\section{Pembinaan}

Kaitannya dengan upaya melembagakan atau membudayakan partisipasi masyarakat, maka perlu dikaji dan dicermati partisipasi masyarakat tersebut sehingga benar-benar menjadi sebuah kebutuhan, bukan sekedar aktivitas yang temporal. Menyadari hal ini, MTs Muhammadiyah 3 Al Furqon Banjarmasin mencoba mengambil langkah-langkah yang diharapkan dapat melembagakan dan membudayakan partisipasi masyarakat dalam pendidikan.

Menyadari hal tersebut, pihak MTs Muhammadiyah 3 Al Furqon Banjarmasin mencoba memprogramkan pertemuan anggota komite madrasah secara berkala dan rutin yaitu 4 bulan sekali. Melalui pertemuan ini diharapkan tidak hanya membahas masalah pendanaan saja tetapi semua aspek penyelenggaraan pendidikan pada MTs Muhammadiyah 3 Al Furqon Banjarmasin. Dalam acara ini seluruh anggota komite madrasah diberikan kebebasan untuk menyampaikan pendapat, gagasan, kritikan, saran bahkan keberatankeberatannya terhadap penyelenggaraan pendidikan pada MTs Muhammadiyah $3 \mathrm{Al}$ Furqon Banjarmasin. Diharapkan jika pertemuan rutin ini dapat terlaksana, maka partisipasi masyarakat dalam pendidikan pada MTs Muhammadiyah 3 Al Furqon Banjarmasin tetap terjaga, terpantau dan semakin meningkat.

Temuan data di atas, menunjukkan bahwa MTs Muhammadiyah 3 Al Furqon Banjarmasin telah melakukan berbagai strategi dan pendekatan untuk membina dan menumbuhkembangkan partisipasi masyarakatnya dalam pendidikan. Sekolah sebagai lembaga yang berfungsi sebagai sistem terbuka dalam agen pembaharuan terhadap masyarakatnya, lembaga pendidikan senantiasa selalu mengikutsertakan masyarakat agar lebih efektif. Karenanya setiap aktivitas pendidikan yang bersifat inovatif selalu dikomunikasikan terlebih dahulu kepada warga masyarakat.

Untuk mengikutsertakan masyarakat dalam pembangunan pendidikan di sekolah, para manajer pendidikan melalui tokoh-tokoh masyarakat aktif menggugah perhatian mereka. Para manajer dapat mengundang para tokoh masyarakat untuk membahas bentuk- bentuk kerjasama dalam meningkatkan pendidikan. Dalam pertemuan ini mereka dapat mengemukakan pendapat, bertukar pikiran untuk menemukan alternatif-alternatif yang terbaik.

Komunikasi tentang pendidikan kepada masyarakat tidak cukup hanya dengan informasi verbal saja. Informasi ini perlu dilengkapi dengan pengalaman nyata yang ditunjukkan kepada masyarakat, agar tumbuh citra positif tentang pendidikan di kalangan mereka. Masyarakat pada umumnya ingin adanya bukti nyata sebelum mereka memberikan dukungan terhadap sesuatu, begitu juga dalam hal pendidikan. Hal yang paling penting dilakukan lembaga pendidikan adalah mampu menyediakan lulusan yang siap pakai di masyarakat, inilah tantangan yang harus dihadapi lembaga pendidikan sebagai konsekuensi diberlakukannya desentralisasi pendidikan.

Secara lebih khusus Pidarta mengemukakan beberapa cara yang dapat ditempuh oleh sekolah dalam rangka mengelola partisipasi masyarakat sebagai berikut:

1. Mengunjungi rumah-rumah dalam rangka memecahkan masalah pendidikan atau membina persahabatan;

2. Menunjukkan sikap positif terhadap orang tua tentang kemajuan puteranya secara tertulis atau lewat telepon; 
3. Bekerjasama dengan masyarakat mengembangkan kebijakan pekerjaan rumah putera-puteri mereka;

4. Berusaha mencari jalan untuk memperbaiki komunikasi antar lembaga dengan masyarakat; dan

5. Menghargai warga masyarakat yang terampil dengan cara memanfaatkannya sebagai narasumber.

\section{KESIMPULAN}

1. Bentuk partisipasi masyarakat dalam pendidikan pada MTs Muhammadiyah 3 Al Furqon Banjarmasin cukup beragam, yakni 1) partisipasi sebagai pengurus komite madrasah, 2) partisipasi dalam berbagai kegiatan-kegiatan di sekolah/madrasah, dan c3) partisipasi masyarakat dalam menjaga keamanan sekolah/madrasah;

2. Strategi dan pendekatan yang telah dilakukan dalam rangka membina dan menumbuhkembangkan partisipasi masyarakat dalam pendidikan pada MTs Muhammadiyah 3 Al Furqon Banjarmasin meliputi tiga hal yakni: 1) Identifikasi Masalah; 2) Perlakuan dan Pendekatan; dan 3) Pembinaan.

\section{DAFTAR PUSTAKA}

Ariani, Manajemen Partisipasi pada Pelaksanaan PSG di SMK Kabupaten Banjar, Tesis Tidak Dipublikasikan, Banjarmasin: Universitas Lambung Mangkurat, 2006

Ganis, Masalah Pendidikan Indonesia. http://www.ganis.blogspot.com, diunduh tanggal 21 Februari 2013

Konkon dan Suryatna, Sejarah Azas-Azas dan Teori-Teori Pengembangan Sosial, Bandung: LP3S IKIP, 1978

Manaf, Abdul, Pengambilan Keputusan Partisipatif (Studi Kasus Pelaksanaan Pengambilan Keputusan di SD Muhammadiyah 8 Banjarmasin). Tesis Tidak Dipublikasikan. Banjarmasin: Universitas Lambung Mangkurat, 2008.

Ngalimun. Bimbingan Konseling di SD/MI Suatu Pendekatan Proses. Yogyakarta: Aswaja Pressindo 2014

Ngalimun. Psikologi Perkembangan Konsep Dasar Perkembangan Kreativitas. Yogyakarta: Aswaja Pressindo. 2016

Pidarta, Made, Manajemen Pendidikan di Indonesia, Jakarta: Rineka Cipta, 2004

Redaktur Koran Pendidikan, Mendorong Partisipasi Aktif Masyarakat dalam Pendidikan, dalam http://wacana.koranpendidikan.com/view/750/mendorong-partisipasi-aktif- masyarakat-dalam-pendidikan.html, diunduh tanggal 22 Februari 2013 PP. No. 39

Tahun 1992 Bab III Pasal 4

Undang-Undang Republik Indonesia No. 20 Tahun 2003 tentang Sistem Pendidikan Nasional, Bagian Kesatu Hak dan Kewajiban warga Negara. 